\title{
HUBUNGAN TINGGI BADAN DENGAN UKURAN LEBAR PANGGUL PADA MAHASISWI ANGKATAN 2010 FAKULTAS KEDOKTERAN UNIVERSITAS SAM RATULANGI
}

\author{
${ }^{1}$ Cristie Y. Laming \\ ${ }^{2}$ George N. Tanudjaja \\ ${ }^{2}$ Sonny J. R. Kalangi \\ ${ }^{1}$ Kandidat Skripsi Fakultas Kedokteran Universitas Sam Ratulangi Manado \\ ${ }^{2}$ Bagian Anatomi - Histologi Fakultas Kedokteran Universitas Sam Ratulangi \\ Email : j_and_crist@yahoo.com
}

\begin{abstract}
Body weight is one of growth indicators. The result of previous research show that women with less than 145 centimeter body weight are potentially has a pelvic stricture. Pelvic stricture is able to cause a coccygeal presentation that can cause natal death. The purpose is to know the correlation of body height and pelvic width which are distansia spinarum and distansia tuberum. The method of this research is observational - analytic using cross sectional design. The study was conducted for three weeks. The amount of the subject is 80 subjects. The measure of body height and pelvic width of the subjects was being analyzed by the Pearson Correlation Analysis with $\alpha=0,05$. The result show that there was a significant correlation of body height and measure of distansia spinarum with correlation coefficient $+0,479$. In the other side, there was nothing significant correlation of body height and measure of distansia tuberum with correlation coefficient $+0,088$. Conclusion: There have significant correlation of body height and measure of distansia spinarum but there have no significant correlation of body height and measure of distansia tuberum.
\end{abstract}

Keywords: Body height, Pelvic Width Measure, Pelvic Stricture

\begin{abstract}
Abstrak: Tinggi badan merupakan salah satu indikator pertumbuhan yang dapat dipengaruhi oleh banyak faktor. Penelitian sebelumnya menyebutkan bahwa wanita yang memiliki tinggi badan kurang dari $145 \mathrm{~cm}$ berpotensi memiliki panggul sempit yang dapat menyebabkan kelainan letak sungsang dan mengakibatkan kematian perinatal. Tujuan penelitian yaitu mengetahui hubungan antara tinggi badan dengan ukuran lebar panggul yaitu hubungan antara tinggi badan dengan ukuran distansia spinarum dan distansia tuberum. Metode penelitian yakni observasional- analitik dengan rancangan penelitian cross sectional. Penelitian ini dilakukan selama tiga minggu. Subjek yang diambil adalah 80 orang mahasiswi angkatan 2010. Subjek diukur tinggi badannya, kemudian diukur ukuran lebar panggul yaitu distansia spinarum dan distansia tuberum, lalu dianalisis menggunakan analisis korelasi Pearson dengan nilai $\alpha=0,05$. Hasil penelitian ditemukan bahwa terdapat hubungan bermakna $(\mathrm{p}=0,000)$ antara tinggi badan dengan ukuran distansia spinarum dengan koefisien korelasi $+0,479$ sedangkan hubungan tinggi badan dengan ukuran distansia tuberum kurang bermakna $(p=0,436)$ dengan koefisien korelasi $+0,088$. Simpulan: Terdapat hubungan bermakna antara tinggi badan dengan ukuran distansia spinarum namun tidak terdapat hubungan yang bermakna antara tinggi badan dengan ukuran distansia tuberum.
\end{abstract}

Kata kunci: Tinggi Badan, Ukuran Lebar Panggul, Panggul Sempit. 
Tubuh tersusun atas sel-sel yang membentuk jaringan dan juga organ yang memiliki tugas dan fungsi khusus. ${ }^{1,2}$ Tubuh manusia dipelajari dalam keadaan berdiri tegak dengan kedua lengan disisi terbuka dan telapak tangan menghadap ke depan yang disebut posisi anatomi dan mempunyai bagian-bagian yang dapat diukur. ${ }^{1,3}$

Metode pengukuran tubuh manusia disebut antropometri. Pengukuran yang penting dalam antropometri yaitu pengukuran dimensi tubuh. Pengukuran dimensi tubuh terdiri atas pengukuran dimensi statis dan dinamis. Dimensi statis diukur pada saat tubuh manusia berada dalam posisi diam di tempat sedangkan dimensi dinamis diukur pada saat manusia menggerakkan badannya pada sikap-sikap posisi kerja tertentu. Dimensi tubuh yang diukur pada sikap berdiri standar antara lain tinggi badan. 3,4

Tinggi badan merupakan salah satu indikator pertumbuhan selain berat badan, erupsi gigi dan pertumbuhan tulang. ${ }^{5}$ Tinggi badan dipengaruhi oleh banyak faktor. Faktor internal yaitu faktor gen dan keadaan hormonal. Faktor eksternal yang mempengaruhi proses pertumbuhan dan perkembangan makhluk hidup berasal dari faktor lingkungan. Faktor lingkungan yang mempengaruhi pertumbuhan dan perkembangan makhluk hidup adalah yaitu gizi, penyakit kronis dan kelainan kongenital, dan keadaan sosial ekonomi. ${ }^{6,7}$ Nutrisi termasuk salah satu faktor lingkungan yang berpengaruh pada tumbuh kembang tulang sejak prenatal. ${ }^{8}$

Variabel-variabel struktur tubuh dapat berupa perbandingan antar ukuran tubuh dapat membedakan antara laki-laki dan perempuan. Perempuan memiliki panggul yang lebih lebar dibandingkan bahu dan kedua spina iliaka anterior superior (SIAS) terpisah dengan jarak yang lebih lebar, sedangkan laki-laki memiliki bahu yang lebih lebar dibandingkan panggul dan kedua SIAS terpisah dengan jarak yang tidak begitu lebar. Perempuan memiliki tulang pelvis yang lebih tipis dengan sudut suprapubik yang lebih besar dan pintu keluar pelvis yang lebih luas daripada pria. $^{3,9}$

Kelainan letak dalam persalinan mengakibatkan timbulnya kematian perinatal. ${ }^{10-12}$ Faktor yang dapat menyebabkan kelainan letak sungsang diantaranya paritas ibu dan bentuk panggul ibu yaitu pada panggul sempit, dikarenakan fiksasi kepala janin yang tidak baik pada pintu atas panggul. Hal ini sesuai dengan penelitian yang dilakukan oleh Mulyawati (2011) yang mendukung teori Rustam Mochtar yang menyebutkan bahwa wanita yang memiliki tinggi badan $145 \mathrm{~cm}$ berpotensi memiliki panggul sempit dan berisiko mengalami tindakan persalinan operasi sectio caesarea. ${ }^{10,13}$

Tujuan dari penelitian ini adalah untuk mengetahui hubungan tinggi badan dengan ukuran lebar panggul khususnya distansia spinarum dan distansia tuberum pada mahasiswi angkatan 2010 Fakultas Kedokteran Universitas Sam Ratulangi.

Berdasarkan hal tersebut maka penulis tertarik melakukan penelitian untuk mengetahui hubungan antara tinggi badan dengan ukuran lebar panggul pada wanita. Oleh sebab itu maka penulis akan melakukan penelitian mengenai hubungan tinggi badan dengan ukuran lebar panggul pada mahasiswi Fakultas Kedokteran Universitas Sam Ratulangi pada bulan November 2012.

\section{METODE}

Metode penelitian ini adalah observasional-analitik dengan desain penelitian cross sectional. Penelitian dilaksanakan pada minggu kedua bulan November sampai minggu pertama bulan Desember 2012 di Fakultas Kedokteran Universitas Sam Ratulangi Manado. Populasi dari penelitian ini adalah mahasiswi angkatan 2010 Fakultas Kedokteran Universitas Sam Ratulangi dengan kriteria inklusi: wanita berusia 19-21 tahun, Indeks Masa Tubuh (IMT) kurang dari 23, tidak ada riwayat cacat pada kedua tungkai, bersedia untuk ikut serta dalam penelitian; dan kriteria eksklusi tidak berada di tempat pada saat pengukuran. Sampel diambil menggunakan metode purposive sampling. Tinggi badan yang diukur adalah jarak dari tumit sampai 
verteks dalam posisi tegak lurus terhadap lantai. Ukuran lebar panggul yang diukur menyangkut distansia spinarum, diukur dari jarak antara SIAS kanan dan kiri; dan distansia tuberum diukur dari jarak antara tuber iskii kanan dan kiri.

Instrumen penelitian yang digunakan adalah lembar persetujuan yang berisi penjelasan mengenai proses pelaksanaan penelitian dan disetujui serta ditanda tangani oleh subjek; lembar isian data yang berisi identitas subjek; antropometer digunakan untuk pengukuran lebar panggul; stature meter digunakan untuk pengukuran tinggi badan dengan satuan $\mathrm{cm}$ yang panjangnya $200 \mathrm{~cm}$ dengan ketelitian 0,1 cm; dan alat tulis menulis. Data-data hasil penelitian dianalisis dengan analisis korelasi Pearson menggunakan aplikasi SPSS (Statistical Package for the Social Science) 20 dengan nilai $\alpha=0,05$.

\section{HASIL PENELITIAN}

Jumlah sampel pada penelitian ini adalah 80 orang mahasiswi Fakultas Kedokteran Universitas Sam Ratulangi angkatan 2010 berusia 19-21 tahun.

Tabel 1. Hasil Pengukuran Tinggi Badan.

\begin{tabular}{cccccc}
\hline Tinggi Badan (cm) & Jumlah & Min (cm) & Max (cm) & Mean (cm) & Std. Deviation \\
\hline$<149,9$ & 9 & 144 & 149 & 147,00 & 1,58 \\
$150-154,9$ & 22 & 150 & 154 & 152,27 & 1,39 \\
$155-159,9$ & 26 & 155 & 159 & 157,69 & 1,16 \\
$160-164,9$ & 13 & 160 & 164 & 161,62 & 1,76 \\
$>165$ & 10 & 165 & 168 & 166,10 & 0,99 \\
\hline TOTAL & 80 & \multicolumn{5}{c}{} \\
\hline
\end{tabular}

Tabel 2. Distribusi hasil pengukuran distansia spinarum.

\begin{tabular}{ccccccc}
\hline $\begin{array}{c}\text { Distansia } \\
\text { Spinarum } \mathbf{( c m})\end{array}$ & Jumlah & $\begin{array}{c}\text { Persentasi } \\
(\mathbf{\%})\end{array}$ & $\begin{array}{c}\text { Min } \\
(\mathbf{c m})\end{array}$ & $\begin{array}{c}\text { Maks } \\
(\mathbf{c m})\end{array}$ & $\begin{array}{c}\text { Mean } \\
(\mathbf{c m})\end{array}$ & Std. Deviation \\
\hline$<18,9$ & 2 & 2,5 & 18,5 & 18,8 & 18,65 & 0,21 \\
$19,0-19,9$ & 3 & 3,8 & 19,0 & 19,6 & 19,37 & 0,32 \\
$20,0-20,9$ & 7 & 8,8 & 20,3 & 20,8 & 20,54 & 0,19 \\
$21,0-21,9$ & 16 & 20,0 & 21,0 & 21,9 & 21,49 & 0,24 \\
$22,0-22,9$ & 18 & 22,8 & 22,0 & 22,9 & 22,34 & 0,28 \\
$23,0-23,9$ & 14 & 17,5 & 23,0 & 23,9 & 23,44 & 0,31 \\
$24,0-24,9$ & 16 & 20,0 & 24,0 & 24,9 & 24,38 & 0,30 \\
$>25$ & 4 & 5,0 & 25,0 & 25,7 & 25,33 & 0,33 \\
\hline TOTAL & 80 & \multicolumn{7}{l}{}
\end{tabular}

Tabel 3. Distribusi hasil pengukuran distansia tuberum.

\begin{tabular}{ccccccc}
\hline $\begin{array}{c}\text { Distansia } \\
\text { Tuberum }(\mathbf{c m})\end{array}$ & Jumlah & $\begin{array}{c}\text { Persentasi } \\
(\mathbf{\%})\end{array}$ & Min (cm) & $\begin{array}{c}\text { Maks } \\
(\mathbf{c m})\end{array}$ & $\begin{array}{c}\text { Mean } \\
(\mathbf{c m})\end{array}$ & Std. Deviation \\
\hline$<8,4$ & 3 & 3,8 & 7,6 & 8,2 & 8,00 & 0,35 \\
$8,5-9,4$ & 11 & 13,8 & 8,5 & 9,4 & 8,96 & 0,37 \\
$9,5-10,4$ & 29 & 36,3 & 9,5 & 10,4 & 10,03 & 0,33 \\
$10,5-11,4$ & 25 & 31,3 & 10,5 & 11,4 & 10,86 & 0,26 \\
$>11,5$ & 12 & 15,0 & 11,5 & 12,2 & 11,74 & 0,27 \\
\hline TOTAL & 80 & 100 & & & & \\
\hline
\end{tabular}


Tabel 4. Hasil Pengukuran Tinggi Badan dan Ukuran Lebar Panggul.

\begin{tabular}{ccccc}
\hline Variabel & Min $(\mathbf{c m})$ & Maks $(\mathbf{c m})$ & Mean $(\mathbf{c m})$ & Std. Deviation \\
\hline Tinggi badan & 144 & 168 & 156,69 & 5,78 \\
Dis. Spinarum & 18,5 & 25,7 & 22,56 & 1,64 \\
Dis. Tuberum & 7,6 & 12,2 & 10,32 & 0,99 \\
\hline
\end{tabular}

Tabel 5. Distribusi Hasil Pengukuran Lebar Panggul Terhadap Tinggi Badan.

\begin{tabular}{cccccccc}
\hline $\begin{array}{c}\text { Tinggi Badan } \\
(\mathbf{c m})\end{array}$ & Jumlah & \multicolumn{3}{c}{ Distansia Spinarum } & \multicolumn{3}{c}{ Distansia Tuberum } \\
\cline { 3 - 8 } & & $\begin{array}{c}\text { Min } \\
(\mathbf{c m})\end{array}$ & $\begin{array}{c}\text { Maks } \\
(\mathbf{c m})\end{array}$ & $\begin{array}{c}\text { Mean } \\
(\mathbf{c m})\end{array}$ & $\begin{array}{c}\text { Min } \\
(\mathbf{c m})\end{array}$ & $\begin{array}{c}\text { Maks } \\
(\mathbf{c m})\end{array}$ & $\begin{array}{c}\text { Mean } \\
(\mathbf{c m})\end{array}$ \\
\hline$<149,9$ & 9 & 19 & 24,2 & 21,12 & 8,6 & 11 & 9,88 \\
$150-154,9$ & 22 & 18,5 & 23,9 & 21,93 & 7,6 & 12,2 & 10,41 \\
$155-159,9$ & 26 & 19,6 & 24,8 & 22,73 & 8,2 & 12,1 & 10,32 \\
$160-164,9$ & 13 & 22,3 & 25,7 & 23,92 & 8,5 & 11,5 & 10,42 \\
$>165$ & 10 & 20,5 & 25,1 & 23,02 & 8,5 & 12,1 & 10,41 \\
\hline TOTAL & 80 & \multicolumn{10}{c}{}
\end{tabular}

\section{BAHASAN}

Tinggi badan bervariasi antar populasi, antar ras dan berubah dari masa ke masa meskipun pada populasi dan ras yang sama. ${ }^{5}$ Tinggi badan dipengaruhi oleh banyak faktor. ${ }^{6,7}$ Faktor yang berperan diantaranya yaitu hormon pertumbuhan dan genetik. Gangguan perkembangan, baik berasal dari faktor genetik, virus ataupun kelainan nutrisi berpengaruh kuat pada berbagai tahap perkembangan tulang. Hal ini menyebabkan terdapat variasi dalam perkembangan ukuran tulang. ${ }^{8}$ Dari hasil penelitian didapatkan bahwa dari 80 subjek wanita pada usia 19-21 tahun, sebagian besar subjek yaitu 26 subjek (32,5\%) memiliki TB antara 155-159,9 cm (Tabel 1), dengan tinggi badan keseluruhan dari 144-168 cm dengan rerata 156,69 cm (Tabel 4).

Variabel-variabel struktur tubuh dapat berupa perbandingan antar ukuran tubuh. Ukuran panggul laki-laki berbeda dari ukuran panggul perempuan dalam beberapa aspek. ${ }^{3}$ Ukuran luar panggul yang dapat dipergunakan untuk menentukan secara garis besar jenis, bentuk dan ukuran panggul diantaranya adalah distansia spinarum dan distansia tuberum. ${ }^{14,15}$ Data hasil penelitian menunjukan bahwa pada wanita usia 19-21 tahun, rentang distansia spinarum terbanyak antara 22-22,9 cm yaitu sebanyak 18 subjek atau 22,8\% dari total (Tabel 2) dan secara keseluruhan dari 80 subjek memiliki ukuran distansia spinarum yaitu $18,5-25,7 \mathrm{~cm}$ dengan rerata $22,56 \mathrm{~cm}$. Hasil pengukuran distansia tuberum terbanyak pada rentang 9,5-10,4 cm dengan jumlah 29 subjek atau 36,3\% dari total (Tabel 3) dan ukuran distansia tuberum secara keseluruhan dari 80 subjek yaitu 7,6-12,2 cm dengan rerata 10,32 cm (Tabel 4).

Hasil pengukuran yang diambil dari 80 subjek (Tabel 5) yang dikelompokkan berdasarkan rentang tinggi badan, dapat diketahui bahwa pada subjek dengan TB kurang dari 149,9 cm rerata ukuran distansia spinarum adalah 21,12 cm dan rerata ukuran distansia tuberum adalah 9,88 cm; pada subjek dengan TB 150-154,9 cm rerata ukuran distansia spinarum adalah 21,93 cm dan rerata ukuran distansia tuberum adalah 10,41 cm; pada subjek dengan TB 155$159,9 \mathrm{~cm}$ rerata ukuran distansia spinarum adalah $24,8 \mathrm{~cm}$ dan rerata ukuran distansia tuberum adalah 10,32 cm; pada subjek dengan TB 160-164,9 cm rerata ukuran distansia spinarum adalah 23,92 $\mathrm{cm}$ dan rerata ukuran distansia tuberum adalah 10,42 cm; pada subjek dengan TB lebih dari $165 \mathrm{~cm}$ rerata ukuran distansia spinarum adalah 23,02 cm dan rerata ukuran 
distansia tuberum adalah 10,41. Hasil ini menunjukan bahwa terdapat variasi dalam ukuran distansia spinarum dan distansia tuberum seiring dengan perbedaan rentang tinggi badan pada masing-masing kelompok.

Data dari hasil pengukuran tinggi badan ukuran lebar panggul kemudian dianalisis dengan analisis korelasi Pearson. Pada analisis tinggi badan dan distansia tuberum didapatkan nilai p sebesar 0,436. Nilai alfa yang digunakan adalah 0,05 yang menandakan secara statistik hubungan antara tinggi badan dengan ukuran distansia tuberum tidak signifikan atau tidak terdapat hubungan bermakna antara tinggi badan dengan ukuran distansia tuberum, sehingga hipotesis nol diterima. Nilai R (Korelasi Pearson) yang didapatkan sebesar $+0,088$ berarti terdapat korelasi bersifat positif antara tinggi badan dengan distansia tuberum. Korelasi positif artinya jika tinggi badan bertambah maka ukuran distansia tuberum akan bertambah.

Pada analisis tinggi badan dan distansia spinarum didapatkan nilai $\mathrm{p}$ sebesar 0,000. Nilai alfa yang digunakan adalah 0,05 sehingga diketahui bahwa terdapat hubungan bermakna antara tinggi badan dengan ukuran distansia spinarum dengan nilai R ( Korelasi Pearson ) mendekati satu yaitu sebesar $+0,479$. Nilai $R$ sebesar $+0,479$ menandakan terdapat korelasi bersifat positif antara tinggi badan dengan distansia spinarum yang artinya jika tinggi badan bertambah maka ukuran distansia spinarum akan bertambah, menunjukkan bahwa hipotesis nol ditolak. Hasil ini sesuai dengan penelitian yang dilakukan oleh Mulyawati (2011) yang menyebutkan bahwa wanita yang memiliki tinggi badan 145 cm berpotensi memiliki panggul sempit. ${ }^{12}$

\section{SIMPULAN}

1. Terdapat hubungan bermakna antara tinggi badan dengan ukuran distansia spinarum namun tidak terdapat hubungan yang bermakna antara tinggi badan dengan ukuran distansia tuberum.

2. Hasil analisis menunjukan bahwa ter- dapat korelasi positif antara tinggi badan dengan ukuran distansia spinarum dan distansia tuberum yaitu jika tinggi badan bertambah, maka ukuran distansia spinarum dan distansia tuberum akan bertambah.

\section{UCAPAN TERIMA KASIH}

Penulis mengucapkan terima kasih kepada dr. Martha M. Kaseke, M.Kes dan dr. Djon Wongkar, M.Kes, AIFO yang telah memberikan banyak masukan, serta kepada semua pihak yang baik secara langsung maupun tidak langsung telah menumbuhkan ide atau gagasan pada penulis sehingga dapat menyelesaikan artikel ini.

\section{DAFTAR PUSTAKA}

1. Pearce, EC. Anatomi dan Fisiologi untuk Paramedis. Jakarta: PT Grame-dia Pustaka Utama; 2009. p.2, 25,28-30,74.

2. Corwin, EJ. Buku Saku Patofisiologi Edisi 3. Jakarta: EGC; 2009. p.3.

3. Wulandari HW, Iman N, Ticoalu SHR. Perbedaan Indeks Akromio-kristalis Berdasarkan Jenis Kelamin pada Mahasiswa Fakultas Kedokteran Universitas Sam Ratulangi. BIK Biomed. 2007; 3:147-157.

4. Harianto R, Boer A, Satyadi V, Samara D, Sidarta N, Tjhin P, et al. Karakteristik Dimensi Antropometrik Statis Mahasiswa Fakultas Kedokteran Universitas Trisakti usia 19-21 tahun. J Kedokter Trisakti. 2004 ; 23: 93-100.

5. Indriati E. Stature in Yogyakarta's Students and Prehistoric Balinese Circa 1100 A.C. 2002. [cited 2012 Oct 22]. Available from: http://i-lib.ugm.ac.id/ jurnal/detail.php?dataId=7915.

6. Anna LK. Gangguan Penyakit yang Hambat Tinggi Badan Anak. 2012 Aug 9 [cited 2012 Oct 22]. Available from: http://health.kompas.com/read/ 2012/08/09/13473068/Gangguan.Penyakit. yang.Hambat.Tinggi.Badan.Anak.

7. Staf Pengajar Ilmu Kesehatan Anak Fakultas Kedokteran Universitas Indonesia. Buku Kuliah 1 Ilmu Kesehatan Anak. Jakarta: Bagian Ilmu Kesehatan Anak FKUI; 2007. p.390-3.

8. Pudyani PS. Reversibilitas Kalsifikasi Tulang Akibat Kekurangan Protein Pre 
dan Post Natal. Majalah Kedokteran Gigi. 2005; 38 : 115-9.

9. Ernest WA. Anatomi Klinik Edisi Kedua. Tanggerang: Binarupa Aksara Publisher. p. $19-20$.

10. Mahmudah U, Cahyati WH, Wahyuningsih AS. Analisis Faktor Ibu dan Bayi yang Berhubungan Dengan Kejadian Kematian Perinatal. Jurnal Kesehatan Masyarakat. 2011; 1:46-56.

11. Sari NK. Hubungan Tingkat Paritas dan Kejadian Letak Sungsang pada Ibu Bersalin di RSUD dr. R. Koesma Tuban tahun 2008. 2012. [cited 2012 Oct 22]. Available http://journal.stikesnu.com/index.php/jurn aldosen/article/view/47/45.

12. Mulyawati I, Azam M, Ningrum DNA. Faktor-Faktor yang Berhu-bungan dengan Tindakan Persalinan Melalui Operasi Sectio Caesarea. Jurnal Kesehatan Masyarakat. 2011; 1:15-24.

13. Moore KL, Agur AM. Anatomi Klinis Dasar. Jakarta: Hipokrates; 2002.p. 145-7.

14. Yulaikhak L. Seri Asuhan Kebidanan : Kehamilan. Jakarta : EGC; 2008. p. 11-7.

15. Manuaba IBG. Ilmu Kebidanan, Penyakit Kandungan dan Keluarga Berencana, untuk Pendidikan Bidan. Jakarta : EGC; 1998. p. 37, 76. 